\title{
Pengaruh Penggunaan Kolektor Plat Datar pada Pengering Padi Tipe Drum Dryer
}

\author{
Nur Hidayati ${ }^{a}$, Iskandar $R^{a}$ \\ ${ }^{a}$ Jurusan Teknik Mesin, Fakultas Teknik, Universitas Andalas, Kampus Limau Manis, Padang, 25163. Indonesia
}

\section{INFORMASI ARTIKEL}

Sejarah Artikel:

Diterima Redaksi: 08 Februari 2019

Revisi Akhir: 22 Maret 2019

Diterbitkan Online: 29 April 2019

\section{KATA KunCI}

Alat pengering

Drum dryer

Kolektor plat datar

Internal channel walls collectors

KORESPONDENSI

E-mail: iskandarridwan2000@gmail.com

\begin{abstract}
A B S T R A C T
Rice is one of staple food consumed by most Indonesian people. Rice quality can be improved by using a proper post-harvest handling process, for example, the drying process. The rice drying process can be performed by drying it directly under the sunshine or using a dryer system. Conventional drying process using the sunshine takes a long time and the drying quality is difficult to control because the sunshine intensity depends on the weather condition. Furthermore, by using conventional drying process the rice is easily contaminated.

In this research, the drum dryer type of rice drying system is proposed to improve the quality of rice drying process. The drum dryer utilizes mechanical energy from the gasoline engine for rotating the drum. On the inner surface of the drum, stirring blades are installed. This dryer also uses heat coming from internal channel wall solar collectors. The experiment was carried out with variation of motor rotation, air flow velocity, intensity of solar radiation and cycle time. Three or four data are taken from each variation. During the experiment, some drying parameters such as : ambient temperature, collector outlet air temperature and drying chamber temperature are measured. The final masses of dried rice are measured for each experiment parameters variation.
\end{abstract}

From the experiment result it can be concluded that the optimum rice mass reduction rate was obtained for each variation using $905.1 \mathrm{rpm}$ motor rotation, $10 \mathrm{~m} / \mathrm{s}$ air flow rate, $948 \mathrm{~W} / \mathrm{m}^{2}$ intensity of solar radiation and 30 minutes rotation time.

\section{PENDAHULUAN}

Padi (gabah) merupakan salah satu bahan makanan dari biji-bijian tertua di dunia yang dikonsumsi sebagian besar masyarakat dunia termasuk di Indonesia. Padi dikenal dengan nama latin oryzo sativa, termasuk dalam famili rumput-rumputan atau secara istilah disebut graminae.

Kadar air yang terkandung pada padi saat pasca panen sekitar 20-26\%, tergantung dengan tingkat kemasakan, cuaca, waktu panen, dan lain-lain [1]. Jika pasca panen padi tidak segera dikeringkan maka akan menyebabkan penurunan mutu beras yang dihasilkan. Penurunan mutu dapat terjadi karena proses metabolisme yang terjadi bila kadar air gabah masih tinggi, sehingga dapat terjadi reaksi browning enzimatis yang dapat berakibat butir beras berwarna kuning, busuk, rusak maupun hitam [2].

Salah satu daerah di Sumatera Barat yang mempunyai curah hujan yang tinggi yaitu Padang Panjang. Curah hujan di daerah ini sekitar 2281 $\mathrm{mm}$ dengan temperatur rata-rata $22,7^{\circ} \mathrm{C}$ [3]. Hujan yang sering terjadi di daerah ini menyebabkan para petani padi sulit dalam proses penanganan pasca panen. Jika hal ini terjadi terus-menerus dapat 
menurunkan kualitas dan menghambat produksi dari beras. Oleh karena itu, untuk memperoleh padi yang bermutu maka diperlukan penanganan pasca panen yang efektif dan efisien.

Penanganan pasca panen pada padi dilakukan dengan cara pengeringan. Proses pengeringan terbagi dua yaitu secara alami dan buatan. Proses pengeringan secara alami dilakukan melalui penjemuran langsung dengan memanfaatkan radiasi matahari (surya), temperatur, kelembaban udara dan kecepatan angin. Pengeringan dengan cara ini memiliki beberapa kelemahan antara lain, sukar dikontrol, tergantung cuaca, memerlukan tempat yang luas, mudah terkontaminasi dan memerlukan waktu yang lama. Pengeringan buatan dilakukan dengan menggunakan suatu alat pengering.

Salah satu tipe alat pengering pada padi yaitu tipe drum dryer. Pada penelitian sebelumnya sudah dilakukan pembuatan dan pengujian pengering tipe drum dryer, dengan biji kakao sebagai bahan yang dikeringkan dan menggunakan sumber panas yang berasal dari kolektor internal channel walls [4].

Pengaduk yang digunakan pada pengering tersebut masih bersifat konvensional dan letak saluran penghubung antara sumber panas dengan drum belum tepat sehingga menyebabkan terjadinya penumpukan material pada saluran penghubung.

Berdasarkan penelitian yang telah dilakukan tersebut, maka diperlukan pengembangan lebih lanjut tentang alat pengering tipe drum dryer ini. Oleh karena itu, pada penelitian ini akan dilakukan pembuatan dan pengujian alat pengering padi tipe drum dryer dengan memanfaatkan energi mekanik yang berasal dari motor bakar sehingga dapat memutar drum dan memasang sudu-sudu pengaduk pada sisi-sisi permukaan bagian dalam drum. Sedangkan untuk sumber panasnya, berasal dari kolektor surya tipe internal channel walls.

\section{KAJIAN PUSTAKA}

\subsection{Pengeringan}

Pengeringan merupakan suatu cara untuk mengeluarkan atau menghilangkan sebagian besar air dari suatu bahan dengan menggunakan energi panas. Dalam proses pengeringan ini biasanya kandungan air dikurangi sampai dengan batas tertentu dimana mikroba tidak dapat tumbuh lagi pada bahan tersebut [5].

Menurut George Banwatt, alasan yang mendukung proses pengeringan adalah untuk menghambat pertumbuhan mikroorganisme sehingga dapat mempertahankan mutu produk terhadap perubahan fisik dan kimiawi yang disebabkan oleh tingginya kadar air. Proses pengeringan juga dapat mengurangi biaya penyimpanan, pengemasan dan transportasi dalam mempersiapkan produk kering yang akan digunakan pada tahap berikutnya. Disamping itu, proses pengeringan juga dapat menghilangkan kadar air yang ditambahkan pada proses sebelumnya, memperpanjang umur simpan dan memperbaiki kegagalan produk[6].

Ada beberapa keuntungan pengeringan, yaitu :

a. Bahan menjadi lebih tahan lama disimpan.

b. Volume bahan menjadi kecil.

c. Mempermudah dan menghemat ruang pengangkutan.

d. Mempermudah transport.

e. Biaya produksi menjadi murah.

Disamping keuntungan di atas, proses pengeringan juga mempunyai beberapa kelemahan yaitu:

a. Warna berubah.

b. Kandungan vitamin lebih rendah, karena vitamin rentan terhadap panas.

c. Terjadi case hardening, yaitu suatu keadaan dimana permukaan bahan mengeras (kering) sedangkan bagian dalam masih basah (belum kering).

d. Mutu lebih rendah daripada bahan pangan segar.

\subsection{Jenis-Jenis Alat Pengering}

Ada banyak macam alat pengering yang dapat digunakan untuk pengeringan, tergantung pada 
bahan yang akan dikeringkan. Diantara jenis-jenis pengering tersebut adalah [7]:

a. Tray Dryer

Alat ini memiliki penampang berbentuk segi empat, di dalamnya terdapat rak-rak yang digunakan sebagai tempat bahan yang akan dikeringkan.

\section{b. Spray Dryer}

Alat ini digunakan untuk menguapkan dan mengeringkan larutan dan bubur (slurry) sampai kering dengan cara termal, sehingga didapatkan hasil berupa zat padat yang kering.

\section{c. Flat bed dryer}

Alat ini merupakan sebuah bed datar yang biasanya digunakan untuk pengeringan padi.

d. Freeze Dryer

Prinsip kerja dari freeze drying meliputi pembekuan larutan, menggranulasikan larutan yang beku tersebut, mengkondisikannya pada vacum ultra-high dengan pemanasan yang sedang sehingga mengakibatkan air pada bahan pangan tersebut akan menyublim dan akan menghasilkan produk padat (solid product).

e. Drum dryer

Bagian utama dari alat ini adalah silinder logam yang berputar dengan bagian dalam yang berlubang. Skema dari sebuah pengering ini dapat dilihat pada Gambar 1.

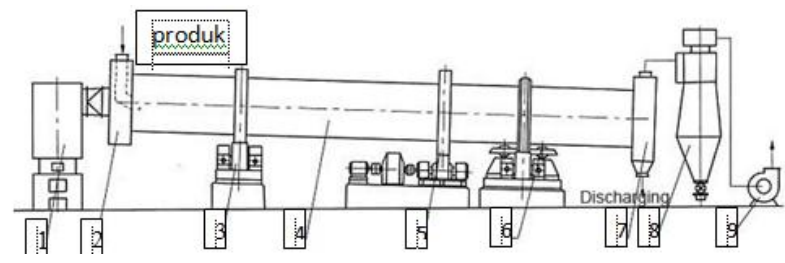

Gambar 1. Drum dryer [7]

Keterangan :
1. Heater
2. Hooper
3. Bingkai penggulung
4. Tempat pengeringan
5. Roda gigi penggerak
6. Perangkat roda gigi
7. Seperangkat alat pengguguran
8. Separator

\section{Blower}

Kelebihan dari penggunaan pengering jenis drum dryer antara lain :

a. Produk yang dihasilkan memiliki porositas yang baik sehingga sifat dehidrasi yang tinggi.

b. Efisien.

c. Produk yang dihasilkan lebih bersih dan higienis.

d. Mudah untuk mengoperasikan dan memelihara.

e. Fleksibel dan cocok untuk beberapa pengeringan.

Kelemahan drum dryer antara lain :

a. Tidak dapat memproses bahan yang mengandung garam tinggi atau bersifat korosif karena berpotensi terjadi pitting pada permukaan drum.

b. Luas kontak permukaan bahan dengan udara lebih rendah dibandingkan dengan jenis pengeringan lainnya seperti spray drying.

\subsection{Pengeringan Padi}

Proses pengeringan gabah merupakan cara untuk menurunkan kadar air gabah dari gabah kering panen (sekitar 23 - $29 \%$ ) menjadi gabah kering giling (sekitar $14 \%$ ). Adapun persyaratan mutu gabah dijelaskan pada Tabel 1 [8].

Tabel 1. Persyaratan mutu gabah [8]

\begin{tabular}{|l|c|c|c|}
\hline \multirow{2}{*}{ Komponen mutu (\% massa) } & \multicolumn{3}{|c|}{ Kualitas } \\
\cline { 2 - 4 } & I & II & III \\
\hline Kadar air & 14 & 14 & 14 \\
\hline Gabah hampa & 1 & 2 & 3 \\
\hline Butir rusak + butir kuning & 2 & 5 & 7 \\
\hline Butir mengapur + gabah muda & 1 & 5 & 10 \\
\hline Butir merah & 1 & 2 & 4 \\
\hline Gabah asing & 0 & 0,5 & 1 \\
\hline Gabah varietas lain & 2 & 5 & 10 \\
\hline
\end{tabular}

Pada Tabel 1 dijelaskan bahwa, kadar air maksimal yang dimiliki oleh gabah kering adalah antara 1314\%. Apabila kadar air gabah lebih tinggi maka gabah sulit dikupas, sedangkan pada kadar air yang lebih rendah butiran gabah akan mudah patah.

Gabah rusak artinya gabah yang terfermentasi, 
gabah berjamur atau gabah yang terserang serangga. Gabah dapat mengalami fermentasi apabila mengalami kontak dengan air dalam waktu cukup lama dan biasanya ditandai dengan adanya warna kehitaman pada permukaan gabah.

Menurut Wongpornchai, untuk penjemuran gabah dengan energi dari sinar matahari memerlukan waktu selama 54 jam paling untuk mencapai kadar air $14,12 \%$ sehingga perlu dilakukan alternatif pengeringan gabah untuk mempersingkat waktu pengeringan [9]. Peneliti lain menyebutkan diperlukan waktu 3-4 hari [10].

Menurut Handserson dan Perry, faktor yang mempengaruhi lamanya proses pengeringan adalah sifat udara pengering, seperti temperatur, kelembaban, arah dan kecepatan aliran udara. Temperatur udara pengering juga sangat berperan dalam menentukan lamanya waktu pengeringan. Biasanya temperatur pengeringan diatur antara $45^{\circ} \mathrm{C}-50{ }^{\circ} \mathrm{C}[11]$.

\subsection{Kolektor Surya}

Kolektor surya adalah suatu alat penangkap radiasi surya untuk menghasilkan energi panas. Dengan demikian dimaksudkan untuk sebanyak mungkin dapat menangkap dan menyerap radiasi lalu diubah menjadi energi termal. Radiasi matahari yang dapat diproses dalam daerah panjang gelombang 0,29 sampai 2,5 $\mu \mathrm{m}$. Kolektor mengubah radiasi matahari yang tidak berkonsentrasi ke dalam panas. Kolektor menggunakan radiasi langsung dan diffusi yang kemudian umumnya tidak meneruskan cahaya tersebut. Kolektor bekerja dalam temperatur permukaan rata-rata di bawah $150{ }^{\circ} \mathrm{C}$ [12].

\subsubsection{Bagian-bagian kolektor surya}

Pada Gambar 2 terdapat bagian-bagian konstruksi dari kolektor surya, dimana syarat-syarat konstruksi suatu kolektor [12]:

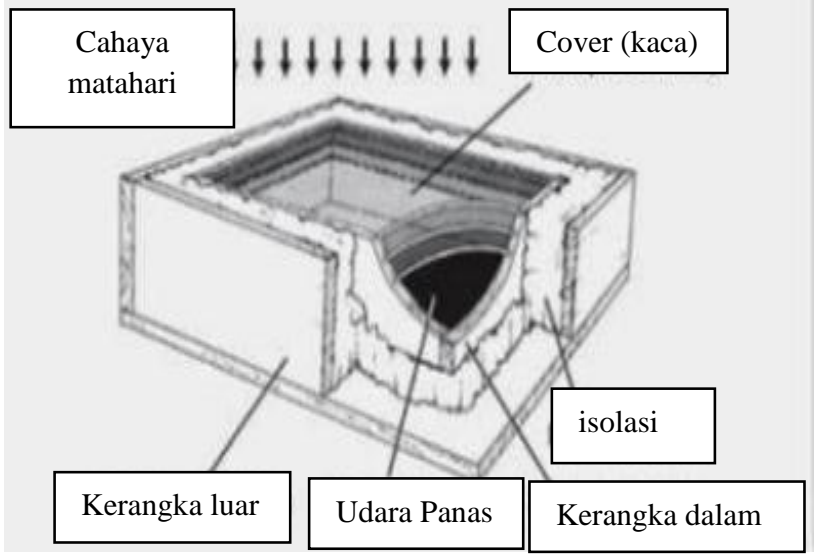

Gambar 2. Bagian-bagian kolektor surya [12]

a. Pada cover diusahakan sebesar mungkin transmisi untuk radiasi gelombang pendek. Lebih mudah dengan cover glass dan mempunyai $\tau=0,9$ untuk radiasi sinar tegak lurus.

b. Absorber diusahakan dari bahan yang mampu menyerap banyak energi matahari sebagai panas.

c. Kerugian panas ke sekeliling diusahakan sekecil mungkin dengan banyak menggunakan lapis insulation.

d. Perpindahan panas antara absorber dan fluida pembawa panas diusahakan sebesar mungkin, dengan menggunakan material absorber dengan konduktiviti panas yang tinggi dan pipa atau kanal aliran dibuat sejauh mungkin secara turbulen [12].

\subsubsection{Kolektor Udara Tipe Solar Sponge Internal Channel Walls}

Kolektor ini termasuk jenis kolektor dengan udara sebagai medium transport. Kolektor yang terdiri dari cover yang terbuat dari floatglass dengan menggunakan lapisan tipis poly carbonate $(<1$ $\mathrm{mm})$. Lapisan tipis poly carbonate mempunyai transmissive sekitar $90 \%$. Hal sangat penting untuk membuat aliran panjang udara pada kolektor, dan juga udara masuk dari bawah kolektor dan keluar di atas kolektor. Udara panas meningkat dan meningkatkan efisiensi. Solar Sponge didesain dengan bentuk segiempat dengan sisi yang panjang horizontal dapat dilihat pada Gambar 3 [13]. 


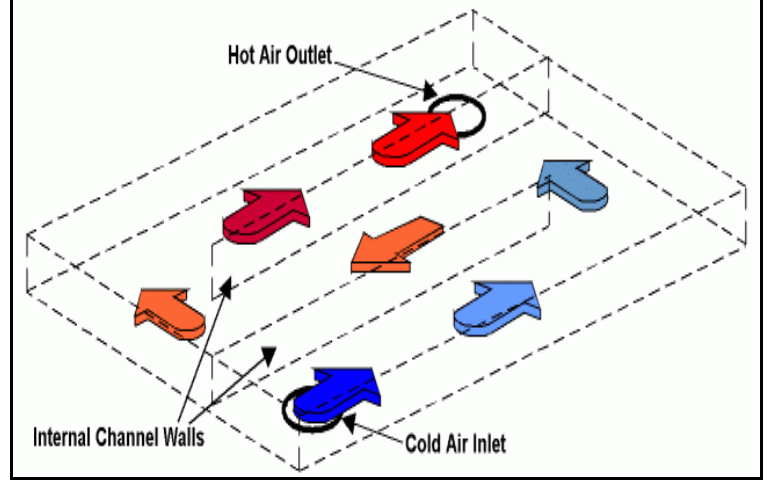

Gambar 3. Kolektor solar sponge internal channel walls [13]

\section{METODOLOGI}

\subsection{Peralatan Penelitian}

Alat pengujian yang digunakan pada penelitian ini ditampilkan pada Gambar 4 dan Gambar 5.

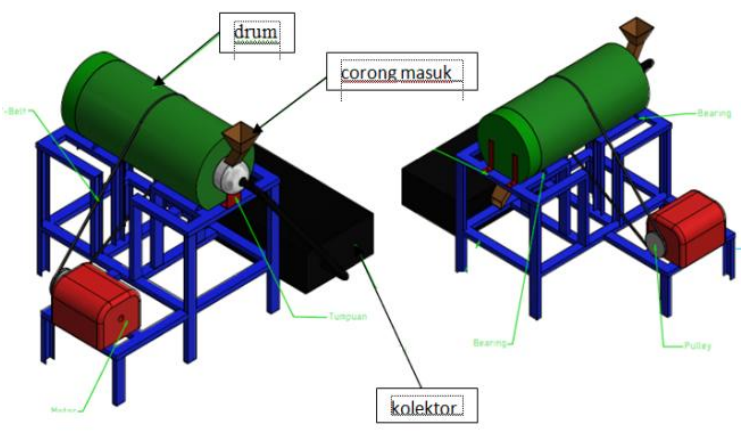

Gambar 4. Skema peralatan penelitian

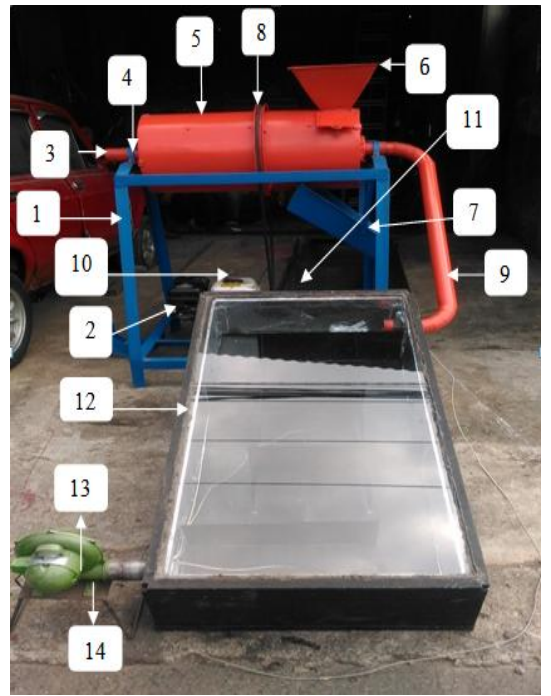

Gambar 5. Foto peralatan penelitian
Keterangan :

1. Kerangka utama

2. Motor bakar

3. Poros

4. Bearing

5. Drum

6. Corong masuk

7. Corong keluar

8. Belt

9. Saluran penghubung

10. Pulley

11. Gearbox

12. Kolektor

13. Blower

14. Kedudukan blower

\subsection{Parameter Penelitian}

Parameter penelitian adalah segala sesuatu yang ditentukan pada penelitian, agar penelitian menjadi tepat dan terarah, maka parameter penelitian ini adalah sebagai berikut:

1. Kecepatan aliran udara (V).

2. Temperatur absorber $\left(\mathrm{T}_{1}, \mathrm{~T}_{2}, \mathrm{~T}_{3}\right)$.

3. Temperatur lingkungan $\left(\mathrm{T}_{\text {in }}\right)$.

4. Temperatur udara keluar dari kolektor $\left(\mathrm{T}_{\text {out }}\right)$.

5. Putaran motor (n).

6. Temperatur ruang pengering $\left(\mathrm{T}_{\mathrm{r}}\right)$.

7. Massa padi sebelum dan sesudah dikeringkan (m).

8. Waktu putaran (t).

9. Intensitas radiasi matahari $\left(\mathrm{E}_{\mathrm{glob}}\right)$.

\section{HASIL DAN PEMBAHASAN}

\subsection{Pengaruh Putaran Motor terhadap Laju Pengurangan Massa Padi}

Pada pengujian ini terdapat variasi putaran motor sebanyak 3 variasi, yaitu : $\mathrm{n}_{1}=603,2 \mathrm{rpm}, \mathrm{n}_{2}=$ $867,7 \mathrm{rpm}$ dan $\mathrm{n}_{3}=905,1 \mathrm{rpm}$, dimana $\mathrm{E}_{\text {glob }}$ sebesar $917,19 \mathrm{~W} / \mathrm{m}^{2}$, waktu putaran 10 menit dan kecepatan aliran udara sebesar $14 \mathrm{~m} / \mathrm{s}$.

Setelah dilakukan pengujian, didapatkan grafik pengaruh putaran motor terhadap laju pengurangan massa padi, yang dijelaskan pada grafik Gambar 6 . 


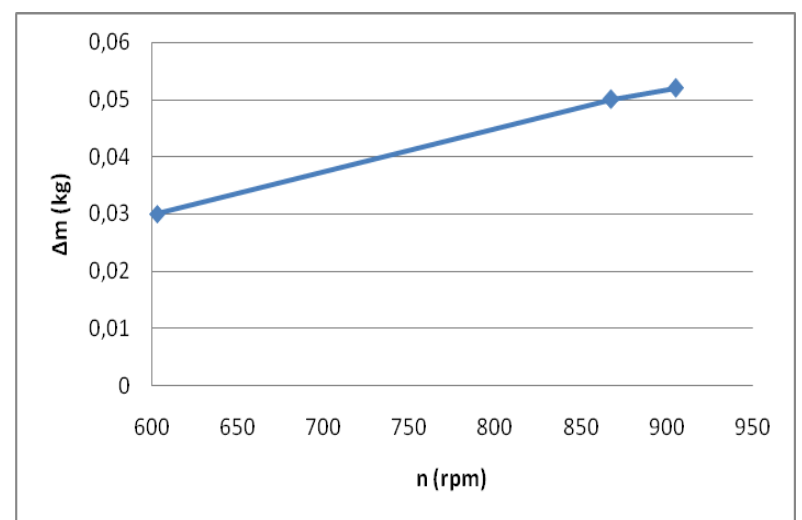

Gambar 6. Pengaruh putaran motor terhadap laju pengurangan massa padi

Dari Gambar 6 dapat dilihat bahwa semakin tinggi putaran motor maka laju pengurangan massa padi semakin besar. Pada pengujian pertama dengan putaran motor 603,2 rpm, didapatkan laju pengurangan massa padi sebesar $0,03 \mathrm{~kg}$. Pengurangan kadar air padi yang dihasilkan pada pengujian ini sebesar $1,2 \%$ per jam. Hal ini membutuhkan waktu selama 11,67 jam untuk mencapai kadar air padi sebesar 14\%. Artinya, lebih cepat 6,3 jam dari penjemuran padi secara konvensional.

Sedangkan pada pengujian kedua dengan putaran motor 867,7 rpm didapatkan laju pengurangan massa padi sebesar $0,05 \mathrm{~kg}$ dengan pengurangan kadar air sebesar $2 \%$ per jam dan membutuhkan waktu selama 7 jam untuk mencapai kadar air padi $14 \%$. Artinya, pengujian ini lebih cepat 11 jam dari pengujian secara konvensional.

Pada pengujian ketiga dengan putaran motor 905,1 rpm didapatkan laju pengurangan massa padi sebesar $0,052 \mathrm{~kg}$ dengan pengurangan massa padi sebesar $0,05 \mathrm{~kg}$ dengan pengurangan kadar air sebesar 2,08\% per jam dan membutuhkan waktu selama 6,73 jam untuk mencapai kadar air padi $14 \%$. Artinya, pengujian ini lebih cepat 11,27 jam dari pengujian secara konvensional.

Antara pengujian pertama, kedua dan ketiga didapatkan hasil yang berbeda. Hal ini dapat dianalisa bahwasanya, semakin tinggi putaran motor maka semakin besar laju penurunan massa padi. Dan ini juga disebabkan oleh semakin banyaknya partikel padi yang bersentuhan dengan udara pengering.

\subsection{Pengaruh Kecepatan Aliran Udara Blower terhadap Laju Pengurangan Massa Padi}

Pada pengujian ini terdapat 3 variasi kecepatan

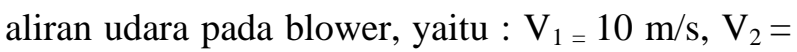
$12 \mathrm{~m} / \mathrm{s}$, dan $\mathrm{V}_{3}=14 \mathrm{~m} / \mathrm{s}$. Adapun intensitas cahaya sebesar 1011,2 W/m², waktu putaran 10 menit dan putaran motor $813 \mathrm{rpm}$.

Kecepatan aliran udara yang bervariasi mempengaruhi temperatur yang keluar dari kolektor $\left(\mathrm{T}_{\text {out }}\right)$, yang dijelaskan pada grafik Gambar 7. Pada saat kecepatan aliran udara yang rendah didapatkan nilai $\mathrm{T}_{\text {out }}$ yang tinggi, yaitu $75^{\circ} \mathrm{C}$. Sebaliknya, ketika kecepatan aliran udara tinggi didapatkan nilai $\mathrm{T}_{\text {out }}$ yang rendah, yaitu $56^{\circ} \mathrm{C}$. Hal ini dapat dianalisa bahwa, semakin tinggi kecepatan aliran udara yang mengalir pada kolektor, maka semakin rendah temperatur keluar kolektor yang dihasilkan.

Selanjutnya, kecepatan aliran udara juga berpengaruh terhadap laju pengurangan massa padi, yang dijelaskan pada grafik Gambar 8 . Berdasarkan Gambar 8, laju pengurangan massa tertinggi, yaitu $0,15 \mathrm{~kg}$ didapatkan ketika kecepatan aliran udara sebesar $10 \mathrm{~m} / \mathrm{s}$, dimana dihasilkan pengurangan kadar air sebesar $6 \%$ per jam. Untuk mencapai kadar air padi sebesar 14\% membutuhkan waktu selama 2,3 jam. Artinya, pengujian pada variasi kecepatan aliran udara ini lebih cepat 15,67 jam dibandingkan pengujian konvensional. Sedangkan, laju pengurangan massa terendah didapatkan ketika kecepatan aliran udara sebesar $14 \mathrm{~m} / \mathrm{s}$, yaitu $0,08 \mathrm{~kg}$ dengan pengurangan kadar air yang dihasilkan sebesar 4\% selama 3,5 jam. 


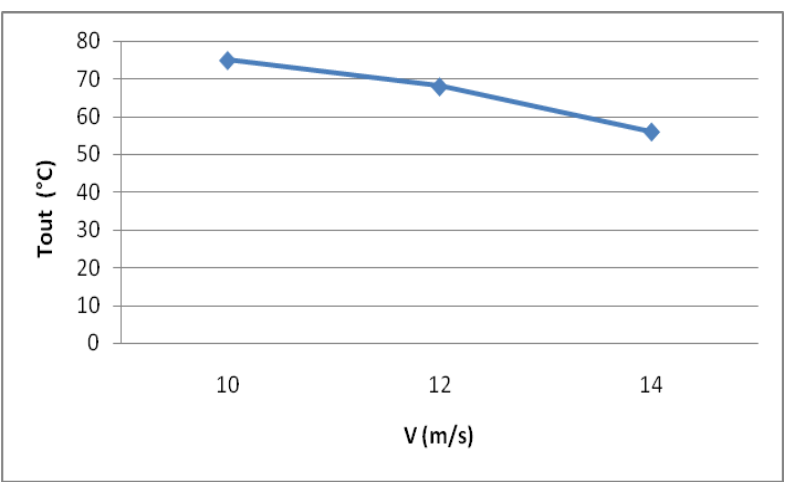

Gambar 7. Pengaruh kecepatan aliran udara terhadap temperatur keluaran kolektor

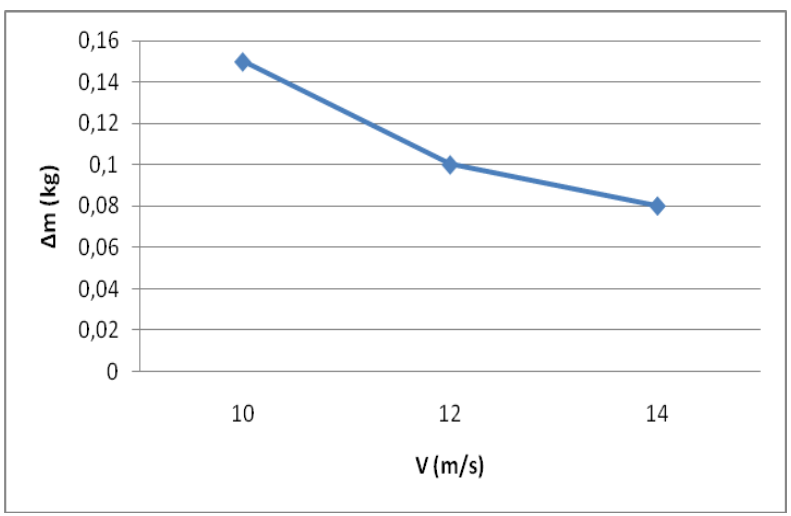

Gambar 8. Pengaruh kecepatan aliran udara terhadap laju pengurangan massa padi

Pengujian ini dapat dianalisa bahwasanya, rendahnya kecepatan aliran udara pada blower menghasilkan laju penurunan massa padi yang besar. Kemudian, tingginya pengurangan kadar air padi yang dihasilkan setelah pengujian membutuhkan waktu yang lebih cepat untuk pengeringan.

\subsection{Pengaruh Intensitas Radiasi Matahari terhadap Laju Pengurangan Massa Padi}

Pada pengujian ini, dilakukan variasi intensitas radiasi matahari $\left(\mathrm{E}_{\text {glob }}\right)$ berdasarkan waktu. Waktu pengujian dimulai dari pukul 10:30 sampai dengan pukul 14:00. Terdapat empat kali pengujian dengan waktu pengujian selama 30 menit. Hal ini dijelaskan pada Gambar 9.

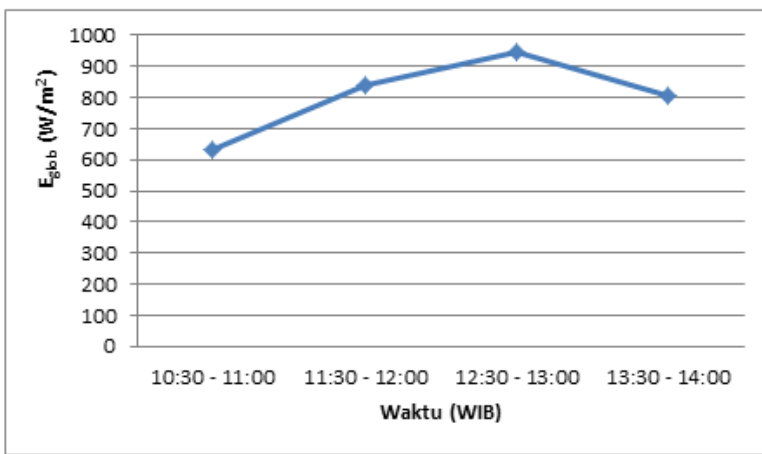

Gambar 9. Pengaruh intensitas radiasi matahari terhadap waktu

Pada grafik Gambar 9, $\mathrm{E}_{\text {glob }}$ tertinggi dihasilkan pada saat pukul 12:30 - 13:00 sebesar $948 \mathrm{~W} / \mathrm{m}^{2}$. Hal ini sesuai dengan teori yang ada, bahwasanya puncak $E_{\text {glob }}$ tertinggi yaitu pada pukul 12:00 sampai 13:00. Adapun $\mathrm{E}_{\text {glob }}$ terendah dihasilkan pada pukul 10:30 - 11:00 sebesar $632 \mathrm{~W} / \mathrm{m}^{2}$.

Dari hasil yang didapatkan dikatakan bahwa intensitas radiasi matahari tertinggi dihasilkan pada 12:30- 13:00. Selanjutnya akan dijelaskan pengaruh intensitas radiasi matahari terhadap laju pengurangan massa padi, seperti yang ditampilkan pada Gambar 10.

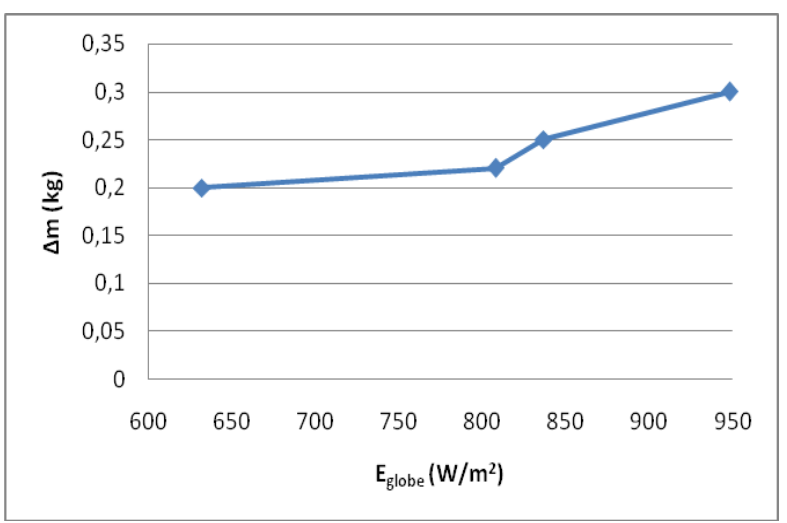

Gambar 10. Pengaruh intensitas radiasi matahari terhadap laju pengurangan masa padi

Berdasarkan Gambar 10, laju pengurangan massa tertinggi adalah $0,3 \mathrm{~kg}$, pada saat $\mathrm{E}_{\text {glob }}$ sebesar 948 $\mathrm{W} / \mathrm{m}^{2}$. Pengujian ini menghasilkan pengurangan kadar air sebesar $4 \%$ per jam dan membutuhkan waktu selama 3,5 jam untuk mencapai kadar air padi $14 \%$. Artinya, pengujian ini lebih cepat 12,75 jam dibandingkan pengeringan secara konvensional. Sedangkan, laju pengurangan massa 
terendah yaitu $0,2 \mathrm{~kg}$ pada saat intensitas radiasi matahari sebesar $632 \mathrm{~W} / \mathrm{m}^{2}$. Pengurangan kadar air yang dihasilkan yaitu 2,67 \%, yang membutuhkan waktu selama 5,25 jam untuk mencapai pengurangan kadar air 14\%. Berdasarkan hasil pengujian ini dapat disimpulkan bahwa semakin tinggi $\mathrm{E}_{\text {glob }}$ yang dihasilkan maka semakin besar laju pengurangan massa padi.

\subsection{Pengaruh Waktu Putaran terhadap Laju Pengurangan Massa Padi}

Pada pengujian ini dilakukan variasi waktu putaran sebanyak tiga kali pengujian. Adapun yang dijaga konstan yaitu, $E_{\text {glob }}$ sebesar $800,27 \mathrm{~W} / \mathrm{m}^{2}$, kecepatan aliran udara $12 \mathrm{~m} / \mathrm{s}$ dan putaran motor sebesar $741 \mathrm{rpm}$. Setelah dilakukan pengujian, didapatkan grafik pengaruh waktu putaran terhadap laju pengurangan massa padi, yang dijelaskan pada Gambar 11.

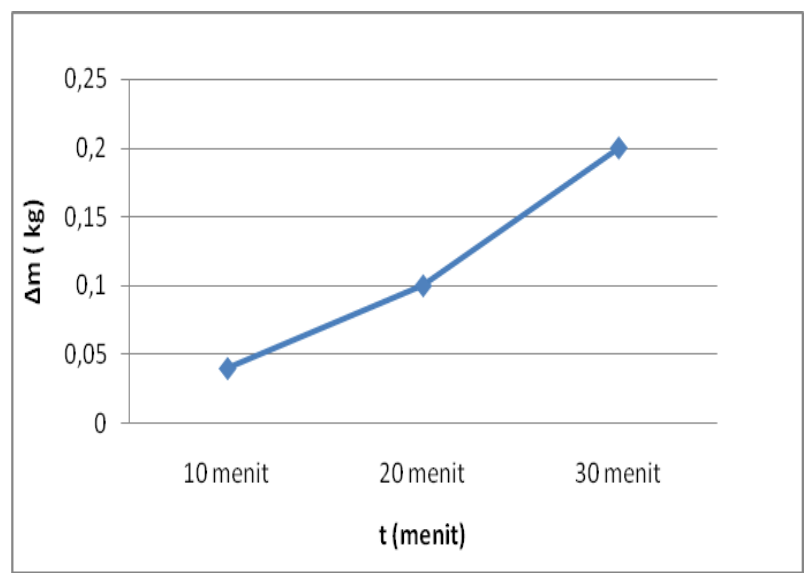

Gambar 11. Pengaruh waktu putaran terhadap laju pengurangan massa padi

Menurut teorinya, semakin lama waktu putaran maka laju pengurangan massa padi akan semakin besar. Hal ini sesuai dengan grafik pada Gambar 11. Pada grafik ini, saat waktu putaran 10 menit maka laju pengurangan massa padi yang dihasilkan sebesar 0,04 kg. Namun, ketika waktu putaran bertambah besar yaitu selama 30 menit, dihasilkan laju pengurangan massa padi yang juga besar, yaitu $0,2 \mathrm{~kg}$.

Pengurangan kadar air pada waktu putaran 10 menit dihasilkan sebesar 1,6\% per jam. Untuk mencapai kadar air padi sebesar $14 \%$ dibutuhkan waktu selama 8,75 jam. Selanjutnya, untuk pengurangan kadar air pada waktu putaran 30 menit dihasilkan sebesar 2,67 \% per jam, dimana untuk mencapai kadar air padi sebesar $14 \%$ dibutuhkan watu selama 5,25 jam. Artinya, pada waktu putaran tertinggi lebih cepat 12,75 jam dari pada pengeringan secara konvensional. Hal ini dapat dianalisa bahwa, semakin lama waktu putaran alat pengering padi, maka semakin besar laju pengurangan massa padi yang dihasilkan. Dan ini juga disebabkan oleh semakin banyaknya partikel padi yang bersentuhan dengan udara pengering, seperti yang dihasilkan oleh pengaruh putaran motor.

\section{KESIMPULAN}

Dari penelitian yang telah dilakukan dapat diambil beberapa kesimpulan sebagai berikut: (1) Semakin tinggi putaran motor, maka semakin besar laju pengurangan massa padi yang dihasilkan; (2) Semakin tinggi kecepatan aliran udara pada blower, maka semakin rendah temperatur keluar kolektor yang dihasilkan; (3) Semakin rendah kecepatan aliran udara pada blower, maka semakin besar laju pengurangan massa padi; (4) Semakin tinggi intentitas cahaya, maka semakin besar laju pengurangan massa padi; (5) Intensitas cahaya matahari tertinggi yaitu $948 \mathrm{~W} / \mathrm{m}^{2}$ didapatkan pada waktu puncak yaitu pukul 12:30-13:00; (6) Semakin besar waktu putaran drum maka semakin tinggi laju pengurangan massa padi yang dihasilkan.

\section{DAFTAR PUSTAKA}

[1] A. Waries, Teknologi Penggilingan Padi, Gramedia Pustaka Utama, Jakarta, 2006.

[2] S. Nugraha, Inovasi Teknologi Pascapanen untuk Mengurangi Susut Hasil dan Mempertahankan Mutu Gabah/Beras di Tingkat Petani, Buletin Teknologi Pertanian Vol 8 (1), Balai Penelitian dan Pengembangan Pertanian, 2012.

[3] BMKG, Prakiraan Cuaca Kota Padang Panjang, 2017, tersedia pada http://www.bmkg.go.id/cuaca/prakiraancuaca.bmkg?Kota=Padangpanjang\&AreaID $=$ 501547\&Prov=32, akses tanggal 17 November 2017. 
[4] Wayan Afri Putra, Penggunaan Kolektor Surya Tipe Internal Channel Walls untuk Pengeringan Kakao di dalam Drum Dryer dengan Pengaduk, Jurusan Teknik Mesin Fakultas Teknik, Universitas Andalas. Padang, 2017.

[5] Muchtadi, Teknik Pengeringan Hasil Pertanian, 1997, tersedia pada http://ocw.usu.ac.id/course/download/313teknik-

pengeringan/tep_421_slide_teknik_pengering an hasil pertaniand.pdf. akses tanggal 23 Oktober 2017.

[6] George Banwatt, Basic Food Microbiology, The Avi Publishing Company Inc., Connecticut, 1981.

[7] Bent Sorensen, Renewable Energy, Third Edition, Elsevier Academic Press London, 2004.

[8] BSN, Persyaratan Mutu Gabah, 2011, tersedia pada http://websisni.bsn.go.id. akses tanggal 6 November 2017.
[9] S. Wongpornchai, K. Dumri, Jongkaewwattana S. dan B. Siri, Effects Of Drying Methods and Storage Time On The Aroma And Milling Quality Of Rice (Oryza Sativa L.) Cv. Khao Dawk Mali 105, Journal of Food Chemistry. Volume 87, Issue 3:407-414, 2003.

[10] M. Tabasum, dan V.K. Jindal, Effect Of Drying On Moisture Removal Rate And Head Yield Of Basmati-370, Vol. 13, No 4.: 312319, J. Agric. Res. Technol. Pakistan, 1992.

[11] M.S. Henderson dan M.E. Perry, Agricultural Process Engineering, Third edition, The AVI Publishing Company Inc., Westport, 402p, 1976.

[12] Dahnil Zainuddin, Teknologi Energi Surya II, CV. Ferila, Padang, 2010.

[13] Jones David L \& Nicole Jones, SolarSponge The DIY Solar Air Heater, 2010, tersedia pada http://www.solarsponge.com/article.htm. akses tanggal 9 November 2017. 